\title{
A Study on Perception of Religious Tourists on Service Quality of Hotels in South Tamil Nadu
}

\author{
Effulgence \\ Vol. 19, No. 1 \\ January - June, 2021 \\ Rukmini Devi Institute of Advanced Studies \\ E-mail : effulgence@rdias.ac.in, Website : www.rdias.ac.in \\ http://effulgence.rdias.ac.in/user/default.aspx \\ https://dx.doi.org/10.33601/effulgence.rdias/v19/i1/2021/01-15
}

\section{Dr. C. Vethirajan ${ }^{1}$ \\ Dr. R. Ganapathi ${ }^{2} \measuredangle$}

\begin{abstract}
In India, hotel industry is operating in a highly competitive atmosphere and quality of service is one of the most significant strategies to attain competitive advantage for hotels. Services of hotels in many ways are contributing to perceptions of guests towards quality of service. The service quality is essentially the service relating to the expectations of guests and any hotel can win by satisfying those wants of guests. The findings explicates that significant relation is there midst socio-economic profile of religious tourists and their perception on service quality of hotels except marital status. Responsiveness, reliability, assurance and empathy are significantly and positively impacting satisfaction of religious tourists towards hotels. Thus, must provide fittings and fixtures that are comfortable and easily usable and they should handle baggage and telephone calls of religious tourists properly. Hotels should give bed coffee or tea and dinning of food in room and allow religious tourists for late check out if possible. In addition, hotels must provide high quality of food and beverages in sufficient quantity to religious tourists at affordable prices and in convenient timings. Besides, hotels should provide separate and small bed for kids and special complementary breakfast especially for religious tourists. Hotel must provide travel plan and service of pick up and drop and yoga centre for religious tourists and they should give welcome drink and welcome note to make religious tourists happy and comfortable in first instance itself. Hotel employees must have knowledge and capacity to response queries of religious tourist and they should deliver services efficiently.
\end{abstract}

Keywords: Hotels, Perception, Religious Tourists, Satisfaction, Service Quality.

\section{INTRODUCTION}

$\mathrm{I}^{\mathrm{n}}$ India, hotel industry is operating in a highly competitive atmosphere and quality of service is one of the most significant strategies to attain competitive advantage for hotels (Rao and Goel, 2018). Services of hotels in many ways are contributing to perceptions of guests towards quality of service (Sharma, 2014). Superior quality of services of hotels is the major contributor to

1. Professor \& Head, Department of Corporate Secretaryship, School of Management, Alagappa University, Karaikudi, Tamil Nadu, drvethirajan@gmail.com

2. Assistant Professor, Directorate of Distance Education, Alagappa University, Karaikudi, Tamil Nadu, meenaramganapathi@gmail.com 
satisfaction of guests (Gupta, 2015). Any hotel cannot survive in this competitive environment, until it satisfies its guests with good quality service (Gunaratne, 2014). The service quality is essentially the service relating to the expectations of guests and any hotel can win by satisfying those wants of guests. When modern and enhanced quality services are created for guests, then it is critical to fulfill expectations of guests of different categories (Poku et al 2013).

Hotels are realizing that offering superior quality of service is the best way to assure better image and get sizeable amount of guests than other hotels (Davidson, 2003), they deliver superior quality of service in order to fulfill requirements of guest in the most effective means (Azzawi and Naeel, 2010). Almost all hotels are improving satisfaction of guests through higher quality of services and are increasing visit of guests to hotels in future also (Mazumder and Hasan, 2014).

Guest satisfaction is the starting point to describe business goals (Yoon and Uysal, 2005). A long-term and reciprocal relation amidst guests and hotels is very important for Guests' satisfaction and the possibility of their return to the same hotel (Mai and Ness, 2006). Hotels are highly concentrating on improvement of quality of service and prompt delivery to guests for attaining higher degree of guests' satisfaction and revisiting behaviour, ending wirh good relations with guests (Jones et al 2007). Therefore, it is important to study perception of religious tourists on service quality of hotels.

\section{REVIEW ON EARLIER STUDIES}

Aldehayyat et al (2011) stated that tangibles, reliability, empathy, responsiveness and assurance and were highly dependable and they were affecting guests' satisfaction in hotels of star categories.

Kumar et al (2011) confirmed that internet facility, swimming pool, gym and entertainment activities were significant elements of quality of service and it affected satisfaction of customers about hotels.

Boonitt and Rompho (2012) mentioned that quality of service was poor and failed to meet the expectations of customers and it was higher in boutique hotels as compared to business hotels. The dimensions of service quality were affected satisfaction of customers and it led to loyalty of customers towards hotels.

Campos and Marodin (2012) indicated that room features, infrastructure facilities, quality of food, response to doubts of guests and safety in hotel were features of quality of service of hotels.

Motlagh et al (2013) revealed that components of quality of service namely responsiveness, reliability, tangible and values were significantly associated with the degree of satisfaction of guests, whereas, empathy and assurance elements were not associated with the degree of guests' satisfaction.

Kumar and Malik (2013) found that procedure for check in and out, response of employees, variety of services and their standards were significantly influencing satisfaction of guests of hotels.

Tuan and Linh (2014) made clear that assurance, responsiveness, reliability and empathy were affecting the service of quality of hotels and these elements played a major role in measurement of quality of service of hotel and it turn these dimensions affected guests' satisfaction.

Radojevic et al (2014) pointed out that internet, air conditioning, rent for rooms and services were positively and significantly associated with satisfaction of hotel customers.

Debasish and Dey (2015) concluded that the major components of quality of service of luxury hotels were tangibility followed by assurance, reliability, empathy and responsiveness and they had positive and significant effect on satisfaction among customers. 
Faizan Ali (2015) revealed that ambience, care of employees, variety of and beverage, skills and response of employees, reservation and value of services were affecting satisfaction of customers of hotels.

Tabaku and Cerri (2016) found that physical appearance, clean environment, relations with employees and service of front office were affecting the perception of customers about service quality of hotels. The quality of services of hotels had significant impact on customers' satisfaction

Eshetie et al (2016) concluded that communication, responsiveness, tangibility and reliability of hotels had positive and significant relation with satisfaction of hotel customers.

Tefera and Govender (2017) mentioned that dimensions of quality of service and satisfaction of customers had significant and positive relation amidst them. Among dimensions of service quality of hotel, intangible dimension was the main contributor to satisfaction of customer as compared to tangible dominions.

Gupta (2017) stated that tangibility followed by assurance, empathy, responsiveness and reliability were significantly and positively influencing satisfaction of hotel customers.

Min (2018) revealed that components of service quality of hotels namely responsiveness, empathy, reliability, assurance and tangible were significantly affecting satisfaction of guests towards luxury hotel chains.

Alemneh (2018) mentioned that reliability, tangibility, communication, responsiveness and confidence had positive and significant relation with satisfaction of hotel customers.

Sujay and Afza (2019) indicated that tangible, reliability, assurance, empathy and responsiveness had significant and positive correlation with satisfaction of customers on hotels.

Shafiq et al (2019) made clear that all the elements of quality of services except tangibility were positively and significantly impacting satisfaction of hotel customers.

Aksar et al (2020) showed that qualities of food and services of hotels were positively and significantly impacting customers' satisfaction.

Kant et al (2020) pointed out that guests of hotels were highly satisfied with various services rendered by hotels and they were satisfied with appearance, helping nature of employees, quality of food, variety and cost of services and atmosphere of hotels.

\section{RESEARCH GAP}

From the review of earlier studies, it is evident that quality of service of hotels and its relation with satisfaction of customers, tourists or guests are studied briefly. But, there is no study on perception of religious tourists on service quality of hotels in pilgrim centers and its impact on their satisfaction towards hotels. Therefore, this study is conducted.

\section{OBJECTIVES OF THE STUDY}

I) To find relationship between perception of religious tourists on service quality of hotels and their socio-economic profile.

ii) To assess the impact of perceived service quality on satisfaction of religious tourists towards hotels.

\section{HYPOTHESES OF THE STUDY}

I) There is no significant relationship between service quality of hotels in tourism destinations and socio-economic profile of tourists.

ii) There is no significant impact of service quality of hotels in tourism destinations on satisfaction of tourists. 


\section{METHODOLOGY}

The religious tourists who visited pilgrim centers in south Tamil Nadu are selected by using convenience sampling method. The data are collected from 845 religious tourists through interview schedule. Socioeconomic profile of religious tourists is analyzed through percentages and perception of religious tourists on service quality of hotels is examined by using mean and standard deviation. Relationship between perception of religious tourists on service quality of hotels and their socio-economic profile is found by applying t-test and ANOVA test. Impact of perceived service quality on satisfaction of religious tourists towards hotels is assessed by employing multiple regression analysis.

\section{RESULTS}

\section{SOCIO-ECONOMIC PROFILE OF RELIGIOUS TOURISTS}

The socio-economic profile of religious tourists is disclosed in Table-1. Larger than two third of them is domestic tourist (70.89 per cent) and almost two third of them is male (65.21 per cent). More than two fifth of them is in age of 31- 40 years ( 44.85 per cent) and near to one third of them is under graduates (30.89 per cent).

Table 1 : Socio-Economic Profile of Religious Tourists

\begin{tabular}{|l|c|c|}
\hline \multicolumn{1}{|c|}{ Socio-Economic Profile } & Number & $\%$ \\
\hline Komestic & 599 & 70.89 \\
\hline Foreign Gender & 246 & 29.11 \\
\hline \multicolumn{1}{|c|}{ Age } & 551 & 65.21 \\
\hline Male & 294 & 34.79 \\
\hline Female & & 7.46 \\
\hline \multicolumn{1}{|c|}{ Education } & 63 & 21.42 \\
\hline Below 20 Years & 181 & 44.85 \\
\hline $21-30$ Years & 379 & 18.58 \\
\hline $31-40$ Years & 157 & 7.69 \\
\hline $41-50$ Years & 65 & 10.06 \\
\hline Above 50 Years & & 13.61 \\
\hline & 85 & 15.97 \\
\hline Secondary & 115 & 30.89 \\
\hline Higher Secondary & 135 & 20.12 \\
\hline Diploma & 261 & 9.35 \\
\hline Under Graduation & 170 & 15.50 \\
\hline Post Graduation & 79 & \\
\hline Illiterate & & \\
\hline \multicolumn{1}{|c|}{ Monthly Income } & & \\
\hline Less than Rs.25,000 & & \\
\hline
\end{tabular}




\begin{tabular}{|l|c|c|}
\hline Rs.25,001 - Rs.35,000 & 189 & 22.37 \\
\hline Rs.35,001 - Rs.45,000 & 223 & 26.39 \\
\hline Rs.45,001 - Rs.55,000 & 182 & 21.54 \\
\hline More than Rs.55,000 & 120 & 14.20 \\
\hline Marital Status & 626 & 74.08 \\
\hline Married & 219 & 25.92 \\
\hline Unmarried & & \\
\hline
\end{tabular}

Higher than one fourth of them acquire monthly income of Rs.35,001 - Rs.45,000 (26.39 per cent) and almost three fourth of them is married (74.08 per cent).

\section{PERCEPTION OF RELIGIOUS TOURISTS ON SERVICE QUALITY OF HOTELS}

The perception of religious tourists on service quality of hotels is disclosed below.

\subsection{TANGIBLE}

The perception of religious tourists on tangible of hotels is disclosed in Table- 2 .

Table 2 : Tangible

\begin{tabular}{|l|c|c|}
\hline \multicolumn{1}{|c|}{ Tangible } & Mean & $\begin{array}{c}\text { Standard } \\
\text { Deviation }\end{array}$ \\
\hline Hotel has modern fittings and fixtures & 3.83 & 0.97 \\
\hline Hotel has visually attractive facilities & 3.76 & 1.04 \\
\hline Materials of hotel are very much appealing & 3.71 & 0.85 \\
\hline Hotel employees are clean and professional & 3.80 & 1.02 \\
\hline Hotel has comfortable fittings and fixtures & 3.35 & 1.06 \\
\hline Hotel provides good quality of food and beverages & 3.38 & 1.40 \\
\hline Hotel services are offered in convenient timings & 3.36 & 1.29 \\
\hline
\end{tabular}

The religious tourists are agreed with hotel has modern fittings and fixtures, hotel has visually attractive facilities, materials of hotel are very much appealing and hotel employees are clean and professional, but, they are neutral with hotel has comfortable fittings and fixtures, hotel provides good quality of food and beverages and hotel services are offered in convenient timings.

\subsection{ASSURANCE}

The perception of religious tourists on assurance of hotels is disclosed in Table-3. 
Table 3 : Assurance

\begin{tabular}{|l|c|c|}
\hline \multicolumn{1}{|c|}{ Assurance } & Mean & $\begin{array}{c}\text { Standard } \\
\text { Deviation }\end{array}$ \\
\hline Hotel infuses trust in guests & 3.31 & 1.20 \\
\hline Guests are getting safe services & 3.81 & 0.98 \\
\hline Guests are protected during their stay in hotel & 3.75 & 1.08 \\
\hline Hotel employees are well behaved & 3.78 & 1.19 \\
\hline Hotel employees have skills to answer queries & 3.33 & 1.61 \\
\hline $\begin{array}{l}\text { Hotel employees have capability to perform service } \\
\text { effectively }\end{array}$ & 3.39 & 1.34 \\
\hline
\end{tabular}

The religious tourists are agreed with guests are getting safe services, guests are protected during their stay in hotel and hotel employees are well behaved, but, they are neutral with hotel infuses trust in guests, hotel employees have skills to answer queries and hotel employees have capability to perform service effectively.

\subsection{EMPATHY}

The perception of religious tourists on empathy of hotels is disclosed in Table- 4 .

Table 4 : Empathy

\begin{tabular}{|l|c|c|}
\hline \multicolumn{1}{|c|}{ Empathy } & Mean & $\begin{array}{c}\text { Standard } \\
\text { Deviation }\end{array}$ \\
\hline Hotel employees provide personal attention to guests & 3.86 & 0.97 \\
\hline Hotel employees deal guests with caring fashion & 3.89 & 1.03 \\
\hline Hotel employees have the best interest of guests at heart & 3.37 & 1.34 \\
\hline Hotel employees recognize the exact needs of guests & 3.29 & 1.11 \\
\hline Hotel is open for 24 hours to guests & 3.91 & 0.91 \\
\hline
\end{tabular}

The religious tourists are agreed with hotel employees provide personal attention to guests, hotel employees deal guests with caring fashion and hotel is open for 24 hours to guests, but, they are neutral with hotel employees have the best interest of guests at heart and hotel employees recognize the exact needs of guests.

\subsection{RELIABILITY}

The perception of religious tourists on reliability of hotels is disclosed in Table- 5 . 
Table 5 : Reliability

\begin{tabular}{|l|c|c|}
\hline \multicolumn{1}{|c|}{ Reliability } & Mean & $\begin{array}{c}\text { Standard } \\
\text { Deviation }\end{array}$ \\
\hline Hotel gives services exactly as it promised & 3.41 & 1.11 \\
\hline $\begin{array}{l}\text { Hotel employees are dependable in handling problems } \\
\text { associated with services }\end{array}$ & 3.85 & 1.04 \\
\hline Hotel employees do the service right the first time & 3.92 & 1.02 \\
\hline Hotel employees performs my service as I want & 3.42 & 1.16 \\
\hline Hotel has no error in billing and records & 3.88 & 1.06 \\
\hline
\end{tabular}

The religious tourists are agreed with hotel employees are dependable in handling problems associated with services, hotel employees do the service right the first time and hotel has no error in billing and records, but, they are neutral with hotel gives services exactly as it promised and hotel employees performs their service as they want.

\subsection{RESPONSIVENESS}

The perception of religious tourists on responsiveness of hotels is disclosed in Table- 6 .

Table 6 : Responsiveness

\begin{tabular}{|l|c|c|}
\hline \multicolumn{1}{|c|}{ Responsiveness } & Mean & $\begin{array}{c}\text { Standard } \\
\text { Deviation }\end{array}$ \\
\hline $\begin{array}{l}\text { Hotel informs guests correctly when the services will be } \\
\text { provided }\end{array}$ & 3.82 & 0.96 \\
\hline Hotel employees provide prompt services & 3.73 & 1.14 \\
\hline Hotel employees are for all time willing to assist guests & 3.27 & 1.31 \\
\hline $\begin{array}{l}\text { Hotel employees are not busy to respond to requests of } \\
\text { guests }\end{array}$ & 3.30 & 1.32 \\
\hline
\end{tabular}

The religious tourists are agreed with hotel informs guests correctly when the services will be provided and hotel employees provide prompt services, but, they are neutral with hotel employees are for all time willing to assist guests and hotel employees are not busy to respond to requests of guests.

\section{SOCIO-ECONOMIC PROFILE OF RELIGIOUS TOURISTS AND PERCEPTION ON SERVICE QUALITY OF HOTELS}

The distribution of religious tourists based on their perception on service quality of hotels is disclosed in Table7. Based on Mean $\pm S D$, it is broken in to high, moderate and low degrees (Mean $=97.53 ; S D=9.11$ ). 
Table 7 : Degree of Perception on Service Quality of Hotels

\begin{tabular}{|c|c|c|}
\hline Degree of Perception & Number & Percentage \\
\hline Low & 173 & 20.47 \\
\hline Moderate & 563 & 66.63 \\
\hline High & 109 & 12.90 \\
\hline Total & 845 & 100.00 \\
\hline
\end{tabular}

In total religious tourists, 12.90 per cent of them possess high degree of perception, but, 20.47 per cent of them possess low degree of it towards quality of service of hotels.

\subsection{KIND AND PERCEPTION ON SERVICE QUALITY OF HOTELS}

The connection midst kind of religious tourists and their perception on service quality of hotels is disclosed in Table-8.

Table 8 : Kind and Perception on Service Quality of Hotels

\begin{tabular}{|c|c|c|c|c|c|c|}
\hline \multirow{2}{*}{ Kind } & \multicolumn{3}{|c|}{ Degree of Perception } & \multirow{2}{*}{ Total } & \multirow{2}{*}{ t-Value } & \multirow{2}{*}{ Sig. } \\
\hline & Low & Moderate & High & & & \\
\hline Domestic & $\begin{array}{c}105 \\
(17.53)\end{array}$ & $\begin{array}{c}414 \\
(69.11)\end{array}$ & $\begin{array}{c}80 \\
(13.36)\end{array}$ & $\begin{array}{c}599 \\
(70.89)\end{array}$ & \multirow{2}{*}{$3.792^{*}$} & \multirow{2}{*}{.052} \\
\hline Foreign & $\begin{array}{c}68 \\
(27.64)\end{array}$ & $\begin{array}{c}149 \\
(60.57)\end{array}$ & $\begin{array}{c}29 \\
(11.79)\end{array}$ & $\begin{array}{c}246 \\
(29.11)\end{array}$ & & \\
\hline Total & $\begin{array}{c}173 \\
(20.47) \\
\end{array}$ & $\begin{array}{c}563 \\
(66.63) \\
\end{array}$ & $\begin{array}{c}109 \\
(12.90)\end{array}$ & $\begin{array}{c}845 \\
(100.00)\end{array}$ & - & - \\
\hline
\end{tabular}

The values in the brackets are per cent to total

* Significant in $5 \%$ level

In 599 domestic religious tourists, 13.36 per cent of them possess high degree of perception, but, 17.53 per cent of them possess low degree of it towards quality of service of hotels. In 246 foreign religious tourists, 11.79 per cent of them possess high degree of perception, but, 27.64 per cent of them possess low degree of it towards quality of service of hotels.

Domestic and foreign tourists possess different degree of perception on service quality of hotels. The t-value is 3.792 and it is elucidating that significant difference is there in $5 \%$ level midst kind of religious tourists and their perception on service quality of hotels

\subsection{GENDER AND PERCEPTION ON SERVICE QUALITY OF HOTELS}

The connection midst gender of religious tourists and their perception on service quality of hotels is disclosed in Table-9. 
Table 9 : Gender and Perception on Service Quality of Hotels

\begin{tabular}{|c|c|c|c|c|c|c|}
\hline \multirow{2}{*}{ Gender } & \multicolumn{3}{|c|}{ Degree of Perception } & \multirow{2}{*}{ Total } & \multirow{2}{*}{ t-Value } & \multirow{2}{*}{ Sig. } \\
\cline { 2 - 5 } & Low & Moderate & High & & & \\
\hline \multirow{2}{*}{ Male } & 114 & 374 & 63 & 551 & & \\
& $(20.69)$ & $(67.88)$ & $(11.43)$ & $\mathbf{( 6 5 . 2 1 )}$ & \multirow{2}{*}{$11.156^{\text {** }}$} & .000 \\
\cline { 1 - 5 } Female & 59 & 189 & 46 & $\mathbf{2 9 4}$ & & \\
& $(20.07)$ & $(64.28)$ & $(15.65)$ & $\mathbf{( 3 4 . 7 9 )}$ & & - \\
\hline \multirow{2}{*}{ Total } & $\mathbf{1 7 3}$ & $\mathbf{5 6 3}$ & $\mathbf{1 0 9}$ & $\mathbf{8 4 5}$ & - & \\
& $\mathbf{( 2 0 . 4 7 )}$ & $\mathbf{( 6 6 . 6 3 )}$ & $\mathbf{( 1 2 . 9 0 )}$ & $\mathbf{( 1 0 0 . 0 0 )}$ & & \\
\hline
\end{tabular}

The values in the brackets are per cent to total

** Significant in $1 \%$ level

In 551 male religious tourists, 11.43 per cent of them possess high degree of perception, but, 20.69 per cent of them possess low degree of it towards quality of service of hotels. In 294 female religious tourists, 15.65 per cent of them possess high degree of perception, but, 20.07 per cent of them possess low degree of it towards quality of service of hotels.

Male and female tourists possess different degree of perception on service quality of hotels. The $t$-value is 11.156 and it is elucidating that significant difference is there in $1 \%$ level midst gender of religious tourists and their perception on service quality of hotels.

\subsection{AGE AND PERCEPTION ON SERVICE QUALITY OF HOTELS}

The connection midst age of religious tourists and their perception on service quality of hotels is disclosed in Table-10.

Table 10 : Age and Perception on Service Quality of Hotels

\begin{tabular}{|c|c|c|c|c|c|c|}
\hline \multirow{2}{*}{ Age } & \multicolumn{3}{|c|}{ Degree of Perception } & \multirow{2}{*}{ Total } & \multirow{2}{*}{ F-Value } & \multirow{2}{*}{ Sig. } \\
\hline & Low & Moderate & High & & & \\
\hline Below 20 Years & $\begin{array}{c}16 \\
(25.40)\end{array}$ & $\begin{array}{c}38 \\
(60.32)\end{array}$ & $\begin{array}{c}9 \\
(14.28)\end{array}$ & $\begin{array}{c}63 \\
(7.46)\end{array}$ & \multirow{5}{*}{$5.998^{\star *}$} & \multirow{5}{*}{.000} \\
\hline $21-30$ Years & $\begin{array}{c}32 \\
(17.68)\end{array}$ & $\begin{array}{c}129 \\
(71.27)\end{array}$ & $\begin{array}{c}20 \\
(11.05)\end{array}$ & $\begin{array}{c}181 \\
(21.42)\end{array}$ & & \\
\hline $31-40$ Years & $\begin{array}{c}69 \\
(18.21)\end{array}$ & $\begin{array}{c}253 \\
(66.75)\end{array}$ & $\begin{array}{c}57 \\
(15.04)\end{array}$ & $\begin{array}{c}379 \\
(44.85)\end{array}$ & & \\
\hline $41-50$ Years & $\begin{array}{c}40 \\
(25.48)\end{array}$ & $\begin{array}{c}100 \\
(63.69)\end{array}$ & $\begin{array}{c}17 \\
(10.83)\end{array}$ & $\begin{array}{c}157 \\
(18.58)\end{array}$ & & \\
\hline Above 50 Years & $\begin{array}{c}16 \\
(24.62)\end{array}$ & $\begin{array}{c}43 \\
(66.15)\end{array}$ & $\begin{array}{c}6 \\
(9.23)\end{array}$ & $\begin{array}{c}65 \\
(7.69)\end{array}$ & & \\
\hline Total & $\begin{array}{c}173 \\
(20.47)\end{array}$ & $\begin{array}{c}563 \\
(66.63)\end{array}$ & $\begin{array}{c}109 \\
(12.90)\end{array}$ & $\begin{array}{c}845 \\
(100.00)\end{array}$ & - & - \\
\hline
\end{tabular}

The values in the brackets are per cent to total

** Significant in $1 \%$ level 
In 63 religious tourists in age of below 20 years, 14.28 per cent of them possess high degree of perception, but, 25.40 per cent of them possess low degree of it towards quality of service of hotels. In 181 religious tourists in age of 21 - 30 years, 11.05 per cent of them possess high degree of perception, but, 17.68 per cent of them possess low degree of it towards quality of service of hotels. In 379 religious tourists in age of $31-40$ years, 15.04 per cent of them possess high degree of perception, but, 18.21 per cent of them possess low degree of it towards quality of service of hotels.

In 157 religious tourists in age of 41 - 50 years, 10.83 per cent of them degree of perception, but, 25.48 per cent of them possess low degree of it towards quality of service of hotels. In 65 religious tourists in age of above 50 years, 9.23 per cent of them possess high degree of perception, but, 24.62 per cent of them possess low degree of it towards quality of service of hotels.

Toursits in various age groups possess different degree of perception on service quality of hotels. The F-value is 5.998 and it is elucidating that significant difference is there in $1 \%$ level midst age of religious tourists and their perception on service quality of hotels.

\subsection{EDUCATION AND PERCEPTION ON SERVICE QUALITY OF HOTELS}

The connection midst education of religious tourists and their perception on service quality of hotels is disclosed in Table-11.

Table 11 : Education and Perception on Service Quality of Hotels

\begin{tabular}{|c|c|c|c|c|c|c|}
\hline \multirow{2}{*}{ Education } & \multicolumn{3}{|c|}{ Degree of Perception } & \multirow{2}{*}{ Total } & \multirow{2}{*}{ F-Value } & \multirow{2}{*}{ Sig. } \\
\hline & Low & Moderate & High & & & \\
\hline Secondary & $\begin{array}{c}32 \\
(37.65)\end{array}$ & $\begin{array}{c}43 \\
(50.59)\end{array}$ & $\begin{array}{c}10 \\
(11.76)\end{array}$ & $\begin{array}{c}85 \\
(10.06)\end{array}$ & \multirow{6}{*}{$13.430^{* *}$} & \multirow{6}{*}{.000} \\
\hline $\begin{array}{l}\text { Higher } \\
\text { Secondary }\end{array}$ & $\begin{array}{c}28 \\
(24.35)\end{array}$ & $\begin{array}{c}76 \\
(66.09)\end{array}$ & $\begin{array}{c}11 \\
(9.56)\end{array}$ & $\begin{array}{c}115 \\
(13.61)\end{array}$ & & \\
\hline Diploma & $\begin{array}{c}33 \\
(24.44)\end{array}$ & $\begin{array}{c}89 \\
(65.93)\end{array}$ & $\begin{array}{c}13 \\
(9.63)\end{array}$ & $\begin{array}{c}135 \\
(15.97)\end{array}$ & & \\
\hline $\begin{array}{l}\text { Under } \\
\text { Graduation }\end{array}$ & $\begin{array}{c}45 \\
(17.24)\end{array}$ & $\begin{array}{c}178 \\
(68.20)\end{array}$ & $\begin{array}{c}38 \\
(14.56)\end{array}$ & $\begin{array}{c}261 \\
(30.89)\end{array}$ & & \\
\hline Post Graduation & $\begin{array}{c}23 \\
(13.53)\end{array}$ & $\begin{array}{c}118 \\
(69.41)\end{array}$ & $\begin{array}{c}29 \\
(17.06)\end{array}$ & $\begin{array}{c}170 \\
(20.12)\end{array}$ & & \\
\hline Illiterate & $\begin{array}{c}12 \\
(15.19)\end{array}$ & $\begin{array}{c}59 \\
(74.68)\end{array}$ & $\begin{array}{c}8 \\
(10.13)\end{array}$ & $\begin{array}{c}79 \\
(9.35)\end{array}$ & & \\
\hline Total & $\begin{array}{c}173 \\
(20.47)\end{array}$ & $\begin{array}{c}563 \\
(66.63)\end{array}$ & $\begin{array}{c}109 \\
(12.90)\end{array}$ & $\begin{array}{c}845 \\
(100.00)\end{array}$ & - & - \\
\hline
\end{tabular}

The values in the brackets are per cent to total ** Significant in $1 \%$ level 
In 85 religious tourists with secondary, 11.76 per cent of them possess high degree of perception, but, 37.65 per cent of them possess low degree of it towards quality of service of hotels. In 115 religious tourists with higher secondary, 9.56 per cent of them possess high degree of perception, but, 24.35 per cent of them possess low degree of it towards quality of service of hotels. In 135 religious tourists with diploma, 9.63 per cent of them possess high degree of perception, but, 24.44 per cent of them possess low degree of it towards quality of service of hotels.

In 261 religious tourists with under graduation, 14.56 per cent of them possess high degree of perception, but, 17.24 per cent of them possess low degree of it towards quality of service of hotels. In 170 religious tourists with post graduation, 17.06 per cent of them possess high degree of perception, but, 13.53 per cent of them possess low degree of it towards quality of service of hotels. In 79 religious tourists who are illiterates, 10.13 per cent of them possess high degree of perception, but, 15.19 per cent of them possess low degree of it towards quality of service of hotels.

Tourists in various educational backgrounds possess different degree of perception on service quality of hotels. The F-value is 13.430 and it is elucidating that significant difference is there in $1 \%$ level midst education of religious tourists and their perception on service quality of hotels.

\subsection{MONTHLY INCOME AND PERCEPTION ON SERVICE QUALITY OF HOTELS}

The connection midst monthly income of religious tourists and their perception on service quality of hotels is disclosed in Table-12.

Table 12 : Monthly Income and Perception on Service Quality of Hotels

\begin{tabular}{|c|c|c|c|c|c|c|}
\hline \multirow{2}{*}{ Monthly Income } & \multicolumn{3}{|c|}{ Degree of Perception } & \multirow{2}{*}{ Total } & \multirow{2}{*}{ F-Value } & \multirow{2}{*}{ Sig. } \\
\hline & Low & Moderate & High & & & \\
\hline \multirow{2}{*}{ Less than Rs.25,000 } & 32 & 83 & 16 & 131 & \multirow{10}{*}{$7.676^{* *}$} & \multirow{10}{*}{.000} \\
\hline & $(24.43)$ & $(63.36)$ & $(12.21)$ & (15.50) & & \\
\hline \multirow{2}{*}{ Rs.25,001 - Rs.35,000 } & 38 & 133 & 18 & 189 & & \\
\hline & (20.11) & (70.37) & $(9.52)$ & (22.37) & & \\
\hline & 47 & 147 & 29 & 223 & & \\
\hline NS.UU, & $(21.08)$ & $(65.92)$ & $(13.00)$ & (26.39) & & \\
\hline \multirow{2}{*}{ Rs.45,001 - Rs.55,000 } & 34 & 121 & 27 & 182 & & \\
\hline & (18.68) & $(66.48)$ & (14.84) & (21.54) & & \\
\hline \multirow{2}{*}{ More than Rs.55,000 } & 22 & 79 & 19 & 120 & & \\
\hline & (18.33) & $(65.83)$ & (15.84) & (14.20) & & \\
\hline \multirow{2}{*}{ Total } & 173 & 563 & 109 & 845 & \multirow{2}{*}{-} & \multirow{2}{*}{ - } \\
\hline & (20.47) & $(66.63)$ & $(12.90)$ & $(\mathbf{1 0 0 . 0 0 )}$ & & \\
\hline
\end{tabular}

The values in the brackets are per cent to total

** Significant in $1 \%$ level 
In 131 religious tourists acquire monthly income of less than Rs.25,000, 12.21 per cent of them possess high degree of perception, but, 24.43 per cent of them possess low degree of it towards quality of service of hotels. In 189 religious tourists acquire ting monthly income of Rs.25,001 - Rs.35,000, 9.52 per cent of them possess high degree of perception, but, 20.11 per cent of them possess low degree of it towards quality of service of hotels. In 223 religious tourists acquire ting monthly income of Rs.35,001 - Rs.45,000, 13.00 per cent of them possess high degree of perception, but, 21.08 per cent of them possess low degree of it towards quality of service of hotels.

In 182 religious tourists acquire monthly income of Rs.45,001 - Rs.55,000, 14.84 per cent of them possess high degree of perception, but, 18.68 per cent of them possess low degree of it towards quality of service of hotels. In 120 religious tourists acquire ting monthly income of more than Rs.55,000, 15.84 per cent of them possess high degree of perception, but, 18.33 per cent of them possess low degree of it towards quality of service of hotels.

Tourists in various monthly income categories possess different degree of perception on service quality of hotels. The F-value is 7.676 and it is elucidating that significant difference is there in $1 \%$ level midst monthly income of religious tourists and their perception on service quality of hotels.

\subsection{MARITAL STATUS AND PERCEPTION ON SERVICE QUALITY OF HOTELS}

The connection midst marital status of religious tourists and their perception on service quality of hotels is disclosed in Table-13.

Table 13 : Marital Status and Perception on Service Quality of Hotels

\begin{tabular}{|c|c|c|c|c|c|c|}
\hline \multirow{2}{*}{ Marital Status } & \multicolumn{3}{|c|}{ Degree of Perception } & \multirow{2}{*}{ Total } & \multirow{2}{*}{ t-Value } & \multirow{2}{*}{ Sig. } \\
\cline { 2 - 5 } & Low & Moderate & High & & & \\
\hline \multirow{2}{*}{ Married } & 127 & 425 & 74 & $\mathbf{6 2 6}$ & & \\
& $(20.29)$ & $(67.89)$ & $(11.82)$ & $\mathbf{( 7 4 . 0 8 )}$ & \multirow{2}{*}{.660NS } & .198 \\
\hline \multirow{2}{*}{ Unmarried } & 46 & 138 & 35 & $\mathbf{2 1 9}$ & & \\
& $(21.01)$ & $(63.01)$ & $(15.98)$ & $\mathbf{( 2 5 . 9 2 )}$ & & \\
\hline \multirow{2}{*}{ Total } & $\mathbf{1 7 3}$ & $\mathbf{5 6 3}$ & $\mathbf{1 0 9}$ & $\mathbf{8 4 5}$ & - & - \\
& $\mathbf{( 2 0 . 4 7 )}$ & $\mathbf{( 6 6 . 6 3 )}$ & $\mathbf{( 1 2 . 9 0 )}$ & $\mathbf{( 1 0 0 . 0 0 )}$ & & \\
\hline
\end{tabular}

The values in the brackets are per cent to total

NS Non Significant

In 626 religious tourists in married, 11.82 per cent of them possess high degree of perception, but, 20.29 per cent of them possess low degree of it towards quality of service of hotels. In 219 religious tourists in unmarried, 15.98 per cent of them possess high degree of perception, but, 21.01 per cent of them possess low degree of it towards quality of service of hotels.

Married and unmarried tourists are not possessing statistically different degree of perception on service quality of hotels. The t-value is 1.660 and it is elucidating that no significant difference is there midst marital status of religious tourists and their perception on service quality of hotels. 


\section{IMPACT OF PERCEIVED SERVICE QUALITY ON SATISFACTION OF RELIGIOUS TOURISTS TOWARDS HOTELS}

To asses the impact of perceived service quality on satisfaction of religious tourists towards hotels, multiple regression analysis is carried out and the result is disclosed in Table-14. R2 and adjusted R2 are 0.67 and 0.65 sequentially which point up the regression model is in good fit. F-value is 12.145 and it clarifies the regression model is in significant.

Table 14 : Impact of Perceived Service Quality on Satisfaction of Religious Tourists towards Hotels

\begin{tabular}{|c|c|c|c|}
\hline Service Quality Dimensions & $\begin{array}{l}\text { Regression } \\
\text { Coefficients }\end{array}$ & t-Value & Sig. \\
\hline Intercept & $5.358^{* *}$ & 13.032 & .000 \\
\hline Tangible $\left(\mathrm{X}_{1}\right)$ & .086 & 1.896 & .058 \\
\hline Assurance $\left(\mathrm{X}_{2}\right)$ & $.318^{* *}$ & 4.288 & .000 \\
\hline Empathy $\left(X_{3}\right)$ & $.139^{* *}$ & 3.714 & .000 \\
\hline Reliability $\left(\mathrm{X}_{4}\right)$ & $.417^{* *}$ & 7.622 & .000 \\
\hline Responsiveness $\left(\mathrm{X}_{5}\right)$ & $.558^{* *}$ & 9.965 & .000 \\
\hline $\mathrm{R}^{2}$ & 0.67 & - & - \\
\hline Adjusted $\mathrm{R}^{2}$ & 0.65 & - & - \\
\hline $\mathrm{F}$ & $12.145^{* *}$ & - & .000 \\
\hline
\end{tabular}

** Significant in $1 \%$ level

The regression co-efficient of responsiveness, reliability, assurance and empathy are positive and they are statistically significant in $1 \%$ level. Therefore, responsiveness, reliability, assurance and empathy are significantly and positively impacting satisfaction of religious tourists towards hotels.

\section{CONCLUSION}

This study explicates that significant relationship is there midst socio-economic profile of religious tourists and their perception on service quality of hotels except marital status. Responsiveness, reliability, assurance and empathy are significantly and positively impacting satisfaction of religious tourists towards hotels. Thus, must provide fittings and fixtures that are comfortable and easily usable and they should handle baggage and telephone calls of religious tourists properly. Hotels should give bed coffee or tea and dinning of food in room and allow religious tourists for late check out if possible. In addition, hotels must provide high quality of food and beverages in sufficient quantity to religious tourists at affordable prices and in convenient timings. Besides, hotels should provide separate and small bed for kids and special complementary breakfast especially for religious tourists.

Hotel must provide travel plan and service of pick up and drop and yoga centre for religious tourists and they should give welcome drink and welcome note to make religious tourists happy and comfortable in first instance itself. Hotel employees must have knowledge and capacity to response queries of religious tourist and they should deliver services efficiently. Besides, employees of hotels must have best interest of guests at heart and they should fulfill the actual needs of religious tourists 
and hotels must provide services correctly as they assured. In addition, hotel employees should always ready to help religious tourists and must respond properly to the requirements of religious tourists.

\section{ACKNOWLEDGEMENT}

The author and co-author greatly acknowledged that this article has been written with financial support of AURF - RUSA Phase 2.0 grant sanctioned vide Letter No. F. 24-51 / 2014-U, Policy (TN Multi-Gen), Department of Education, Government of India, Dated, 09.10.2018.

\section{REFERENCES}

Aldehayyat, J. S., Khattab, A., \& Suleiman, A. (2011). Perceptions of service quality in Jordanian hotels. International Journal of Business and Management, 6(7), 226-233.

Ali Shafiq, Md Imtiaz Mostafiz, \& Mutsumi Taniguchi. (2019). Using SERVQUAL to determine generation $Y^{\prime}$ 's satisfaction towards hoteling industry in Malaysia. Journal of Tourism Futures,7(1), 62-74.

Azzawi, \& Nabeel. (2010). measuring recognize quality hotel services from the viewpoint of customers: An empirical study of the hotels five star in Amman. Journal of Baghdad College of Economic Sciences University, 25(4), 24-35.

Chandrashekhar Sharma. (2014). A service quality model applied on Indian hotel industry to measure the level of customer satisfaction. International Journal of Science and Research, 3(3), 480-485.

Davidson, M. C. G. (2003). An integrated approach to service quality in hotels. Journal of Quality Assurance in Hospitality and Tourism, 4(1), 7 185.

Deepak Gupta. (2017). Service quality \& customer satisfaction in hotel industry. International Journal of Techno-Management Research, 6(2), 41-55.

Domingos Fernandes Campos, \& Tatiana Gehlen Marodin. (2012). Perceptions of quality and expectations of hotel services. Journal of Operations and Supply Chain Management, 5(1), 82-99.

Ekta Rao, \& Alok Goel. (2018). Factors Causing work related stress in the hospitality sector: A study of employees in three star hotels in Dehradun Region. Effulgence, 16(1), 39-50.

Elvira Tabaku, \& Shpetim Cerri. (2016). An assessment of service quality and customer satisfaction in the hotel sector. Tourism \& Hospitality Industry, 480-489.

Faizan Ali. (2015). Service quality as a determinant of customer satisfaction and resulting behavioural intentions: A SEM approach towards Malaysian resort hotels. Tourism, 63(1), 37-51.

Garima Gupta. (2015). Service versus relationship: An investigation into quality dimensions for loyalty and wom in online retail. Effulgence, 13(2), 132-148.

Gunaratne, U. (2014). Relationship between service quality and customer satisfaction in Sri Lankan hotel industry. International Journal of Scientific and Research Publications, 4(11), 1-8.

Hokey Min. (2018). Measuring the service quality of luxury hotel chains in the USA. International Journal of Services and Operations Management, 30(4), 465-479.

Jay Prakash Kant, Jitender Kumar, \& Amit Kumar. (2020). Guest's perception towards service quality in hotels of Chandigarh. International Journal of Advanced Science and Technology, 29(12), 1786-1792.

Jones D. L., Mak B., \& Sim J. (2007). A new look at the antecedents and consequences of relationship quality in the hotel service environment. Services Marketing Quarterly, 28(3), 15-31.

Kumar, B., Banga, G., \& Thapar, J. (2011). An assessment of service quality of hotel industry. Pacific Business Review International, 4(1), 13-30.

Mai, L.W., \& Ness, M. R. (2006). A structural equation model of customer satisfaction and future purchase of mail-order speciality food. International Journal of Business Science and Applied Management, 1(1), 1-13.

Motlagh, A. T., Sadeh, E., Sadeh, S., Jafari, H., 
Morovat, J. A., \& Enaamzadeh, A. (2013). How does service quality lead to loyalty in the hotel industry in Iran. Research Journal of Applied Sciences, Engineering and Technology, 5(2), 374379.

Muhammad Aksar, Muhammad Bilal Kayani, \& Murad Ali. (2020). A study of customer satisfaction and customer loyalty in the restaurant and hotel industry of Pakistan. Global Journal of Emerging Science, 1(2), 137-151.

Nham Phong Tuan, \& Nguyen Thi Hai Linh. (2014). Impact of service quality performance on customer satisfaction: A case study of Vietnam's five star hotel, ABAC Journal, 34(3), 53-70.

Orthodox Tefera, \& Krishna Govender. (2017). Service quality, customer satisfaction and loyalty: The perceptions of Ethiopian hotel guests. African Journal of Hospitality, Tourism and Leisure, 6(2), 1-22.

Poku, K., Zakari, M., \& Soali, A. (2013). Impact of service quality on customer loyalty in the hotel industry: An empirical study from Ghana. International Review of Management and Business Research, 2(2), 600-609.

Sakun Boonitt, \& Nopadol Rompho. (2012). Measuring service quality dimensions: An empirical analysis of Thai hotel industry. International Journal of Business Administration, 3(5), 52-63.

Sanjeev Kumar, \& Sandeep Malik. (2013). An empirical study of factors affecting hotel guests' satisfaction from front office services \& facilities in Indian hospitality industry. Arth Prabandh: A Journal of Economics and Management, 2(3), 1-8.

Sathya Swaroop Debasish, \& Sabyasachi Dey. (2015). Customer perceptions of service quality towards luxury hotels in ODISHA using servqual model. International Journal of Research in Business Studies and Management, 2(9), 1-9.

Shimekit Kelkay Eshetie, Wondoson Seyoum, \& Seid Hussen Ali. (2016). Service quality and customer satisfaction in hospitality industry: The case of selected hotels in Jimma town, Ethiopia. Global Journal of Management and Business Research: E-Marketing, 16(5), 73-86.
Simachew Alemneh. (2018). The impact of service quality on customer satisfaction: The case of five star hotels in Addis Ababa, Ethiopia. Indian Journal of Applied Research, 8(8), 1-10.

Sujay M. J., \& Noor Afza. (2019). Perceived service quality and customer satisfaction: A study of mid-scale hotel industry in Mysuru. Journal of Management Research and Analysis, 6(1), 54-59.

Suman Mazumder, \& Rashedul Hasan, A. B. M. (2014). Measuring service quality and customer satisfaction of the hotels in Bangladesh: A study on national and international hotel guest. Journal of Tourism and Hospitality Management, 2(1), 95-111.

Tijana Radojevic, Nemanja Stanisic, Nenad Stanic, \& Marko Sarac. (2014), Measuring customer satisfaction in the hospitality industry: an empirical study of the hotels in the capital cities of Europe. E-Business in Tourism and Hospitality Industry, 12(3), 788-795.

Yoon, Y., \& Uysal, M. (2005). An examination of the effects of motivation and satisfaction on destination loyalty: A structural model. Tourism Management, 26(1), 45-56. 